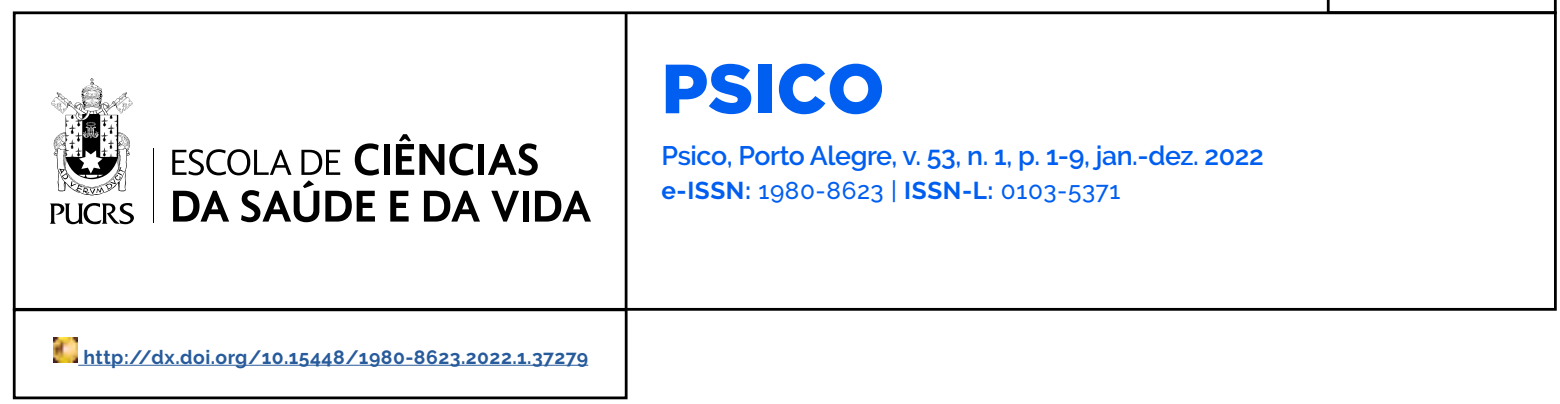

SEÇÃO: ARTIGO

\title{
Obesity and social representations among patients subjected to argon plasma coagulation (APC)
}

\author{
Obesidade e representações sociais entre pacientes submetidos à coagulação \\ de plasma de argônio (APC) \\ Obesidad y representaciones sociales entre pacientes sujetos a coagulación de \\ plasma de argón (APC)
}

Tais Martins ${ }^{1}$

orcid.org/0000-0002-7494-6961

taisprof@hotmail.com

\section{Gislei Mocelin Polli ${ }^{1}$}

orcid.org/0000-0001-7254-7441

gismocelin@gmail.com

\section{Ana Maria Justo 2}

orcid.org/0000-0003-2056-3575

justoanamaria@gmail.com

Recebido em: 4 mar. 2020

Aprovado em: 11 jul. 2021.

Publicado em: 7 mar. 2022
Abstract: This study sought to identify the Social Representations of Obesity among 15 individuals who underwent bariatric surgery through the Roux-en-Y Gastric Bypass (RYGB) method and were subjected to Argon Plasma Coagulation (APC) due to weight relapse. Data were collected through interviews and analyzed via Descending Hierarchical Classification. Obesity was associated with physical limitations and difficulties in social relationships. Prejudice and difficulty in changing habits are associated with the choice to undergo surgical treatment and to weight relapse. The suffering that goes along with obesity and the difficulty in changing habits seem to be associated with the search for surgical help. Keywords: obesity, bariatric surgery, relapse, argon plasma coagulation, social representations

Resumo: Este estudo procurou identificar as representações sociais da obesidade entre 15 individuos submetidos à cirurgia bariátrica pelo método Bypass Gástrico em Y de Roux (RYGB) e submetidos à Coagulação por Plasma de Argônio (APC) devido à recidiva de peso. Os dados foram coletados através de entrevistas e analisados por meio da Classificação Hierárquica Descendente. A obesidade foi associada a limitações físicas e dificuldades nas relações sociais. Preconceito e dificuldades na mudança de hábitos estão associados à escolha de se submeter a tratamento cirúrgico e à recidiva de peso. O sofrimento que acompanha a obesidade e a dificuldade de mudar hábitos parecem estar associados à busca de ajuda cirúrgica.

Palavras-chave: obesidade, cirurgia bariátrica, recidiva, coagulação por plasma de argônio, representações sociais

Resumen: Este estudio buscó identificar las representaciones sociales de la obesidad entre 15 individuos que se sometieron a cirugia bariátrica utilizando el método de bypass gástrico Roux-en-Y (RYGB) y que se sometieron a coagulación con plasma de argón (APC) debido a una recaída en el peso. Los datos fueron recolectados a través de entrevistas y analizados utilizando la Clasificación Jerárquica Descendente. La obesidad se asoció con limitaciones físicas y dificultades en las relaciones sociales. Los prejuicios y las dificultades para cambiar los hábitos están asociados con la opción de someterse a un tratamiento quirúrgico y una recaída del peso. El sufrimiento que acompaña a la obesidad y la dificultad para cambiar los hábitos parecen estar asociados con la búsqueda de ayuda quirúrgica. Palabra clave: obesidad, cirugía bariátrica, recaida, coagulación con plasma de argón, representaciones sociales 
The World Health Organization (WHO, 2019) indicates that obesity is a condition characterized by a body mass index (BMI) greater than or equal to $30.00 \mathrm{~kg} / \mathrm{m}^{2}$. In addition to increased risk of death, it is associated or acts as a predisposing factor for non-fatal conditions that compromise quality of life (Lima \& Oliveira, 2016; Williams et al., 2015). Worldwide, the number of obese individuals has doubled between 1980 and 2014. when prevalence reached $11 \%$ among men and $15 \%$ among women (WHO, 2017). In Brazil, the percentage of women with obesity was $19.6 \%$, while among men it was 18.1\% in 2016 (HF, 2017).

Although weight gain is considered the result of an imbalance in the energy balance, the solution to this equation seems to be more complex than a simple caloric balance. Different health professionals have dedicated themselves to helping people with weight loss and maintenance, but the results have not always been effective or lasting. Conventional (non-surgical) treatment for weight reduction involves the need to change habits that are often rooted in life history and that are reinforced in social relationships (Barros, 2015; Christensen et al., 2018).

When conventional treatments do not provide the desired results, bariatric surgery emerges as an effective method for weight loss among obese individuals (Magouliotis et al., 2019; Vuuren et al., 2016). The most commonly used surgery method, Roux-en-Y Gastric Bypass (RYGB), results in a $35.8 \%$ body weight loss in the first year and $27.7 \%$ in 10 years (Brunaldi et al., 2018). However, a major change in lifestyle of the operated patient is required for weight loss to be sustained (Moura et al., 2019). Nearly 35\% of RYGB-operated patients experience weight relapse (Moon et al., 2018). Relapse is caused by several factors and is related to gastrojejunal anastomosis (GJA) dilatation, in addition to genetic, psychological, environmental and behavioral factors (Brunaldi et al., 2018)

Despite the difficulties in weight loss and maintenance are closely related to the difficulties in changing habits and life style (González-Cutre et al., 2018; Latner \& Ciao, 2013), there are some endoscopic approaches aimed at correcting the GJA dilation. Argon Plasma Coagulation (APC) is an electrocoagulation method that uses an injection of ionized gas into the tissue. In patients with RYGB, this injection has proved to reduce gastrojejunal anastomosis diameter and contribute to a 6 to 10\% body weight loss in one year (Moon et al., 2018). Patients who underwent RYGB and APC suffer from a history of obesity and difficulty in controlling weight through non-surgical life-long techniques, and the expected weight loss after APC is less significant compared to RYGB results, in addition revisional procedures are significantly more challenging than the initial surgery (Brunaldi et al., 2018; Vuuren et al., 2016).

For surgical procedures to be successful, they must be combined with other forms of professional support for operated patients. Only physiological change has been shown to be inefficient in an important percentage of patients, which indicates that other variables need to be considered (González-Cutre et al., 2018; Vuuren et al., 2016). In cases of weight relapse, it is important to understand the associated psychological and social aspects, considering that food and eating habits are social and cultural constructions that go beyond the physiological component (LoMonaco \& Bonetto, 2019).

According to Herzlich (2017), health and illness processes must be understood from their insertion in culture, considering the "lens" through which individuals perceive and interpret the world, which involves the beliefs by which illnesses are recognized and treated. In this sense, Social Representations Theory (SRT), developed by Serge Moscovici in the field of Social Psychology, makes it possible to understand the knowledge shared between people about different social objects, providing theoretical and methodological bases to understand socially shared thoughts and practices concerning body and health. Social Representations (SRs) serve to justify practices, they make up a knowledge that can guide behaviors and form identities (Polli et al., 2018). SRs are forms of knowledge originated in communication processes which enable people to create 
and share the same social reality, guiding their behavior (Jodelet, 2001).

Obesity and the difficulties and health problems related to it, can be better understood by considering the implications that socially shared beliefs have on eating and health practices adopted by different social groups. This view also allows to expand the individual's vision for the group or community, understanding that the physical aspect of obesity can imply a feeling of belonging and identity sharing with other people in the same situation. The SRs approach makes it possible to know the beliefs socially shared by these people, allowing the relationships between the beliefs and the practices adopted to be clarified (Fonte et al., 2017).

It is possible to suppose that people who live with subsequent failures in the attempt to lose weight seek alternatives to the models already tried. Vuuren et al. (2016) identified that the search for surgical procedures after the first surgical intervention is associated, by people who performed such procedures, with the unrealistic expectation of weight loss when performing the first surgery. Even so, patients believe that they are unable to reach their desired weight without external, in this case, surgical, help. These patients believe that surgery can provide control overeating behaviors.

Bariatric surgery emerges as an alternative to conventional models of weight loss, which promises to be definitive. However, in some cases where there has been no success, new possibilities are necessary (Vuuren et al., 2016). The question that motivated the development of this research is related to the search for new medical interventions (APC) to solve the problem among some patients, despite the previous failure. What does obesity represent to these people that motivates them to undergo subsequent medical procedures, which promise a result that they themselves have already experienced that is not true? It is important to obtain a better understanding of the socially constructed meanings about obesity, considering the contexts in which these people are inserted.

Thus, this study sought to understand the knowledge shared about obesity among people who, after having suffered a weight relapse after bariatric surgery, opted to undergo APC as a way to lose weight again. Knowing the meanings and social representations of obesity for these people can provide important psychosocial elements that underlie extreme behaviors for weight loss and maintenance.

\section{Method}

Fifteen individuals participated, eleven females and four males, between 26 and 53 years of age, with an average age of 42.26 years (SD $=8.78$ ) and average BMI of $28.09 \mathrm{Kg} / \mathrm{m} 2$ (SD = 4.57). All participants underwent RYGB, experienced weight relapse, and were subjected to at least one APC. Their original BMI pre RYGB was the minimum 36.20 and the maximum $63.98(M=43.06, S D$ = 7.36). The medical indication for APC was not investigated, however the inclusion criteria of the patients in this study was to have performed APC at least once. Other variables such as schooling and income were not considered as inclusion criteria, with a view to difficulty in obtaining participants to meet the principal inclusion criteria. Table 1 shows the most relevant participant data: 
Table 1 - Characterization of Participants

\begin{tabular}{|c|c|c|c|c|}
\hline & Age & Gender & BMI $\left(\mathrm{kg} / \mathrm{m}^{2}.\right)$ & $\operatorname{APC}(n)$ \\
\hline $\mathrm{P} 1$ & 28 & Female & 25.59 & 2 \\
\hline $\mathrm{P} 2$ & 53 & Female & 28.19 & 4 \\
\hline P3 & 40 & Male & 26.73 & 2 \\
\hline $\mathrm{P} 4$ & 38 & Female & 27.47 & 2 \\
\hline P5 & 52 & Male & 26.51 & 2 \\
\hline P6 & 49 & Female & 34.21 & 1 \\
\hline P7 & 52 & Female & 33.06 & 1 \\
\hline P8 & 34 & Male & 29.94 & 1 \\
\hline P9 & 44 & Female & 29.67 & 5 \\
\hline $\mathrm{P}_{10}$ & 38 & Female & 25.33 & 5 \\
\hline $\mathrm{P}_{11}$ & 41 & Female & 22.16 & 5 \\
\hline $\mathrm{P} 12$ & 39 & Male & 28.09 & 1 \\
\hline $\mathrm{P} 13$ & 26 & Female & 36.72 & 1 \\
\hline P14 & 47 & Female & 29.40 & 7 \\
\hline P15 & 53 & Female & 18.34 & 1 \\
\hline Mean & 42.26 & & 28.09 & \\
\hline SD & 8.78 & & 4.58 & \\
\hline
\end{tabular}

Age in years

Participants were selected from a list provided by a private clinic in the city of Curitiba (Brazil). After previous telephone contact, a personal visit was scheduled according to the best conditions for each interviewee - some were made at the participants' home or work and some were collected at the researcher's office. Participants answered a semi-structured interview aimed at identifying obesity SRs and treatment history.

Medical data were treated using descriptive statistics and data about obesity SRs were subjected to a lexicographic analysis through descending hierarchical classification (DHC) with the aid of the IRaMuTeQ software (Ratinaud, 2009). The steps of the research execution involved the submission and approval the research project to the Human Research Ethics Committee (CEP) of Universidade Tuiuti do Paraná, according to the guidelines of resolution $466 / 12$ issued by the National Health Council. Informed consent was obtained from all individual participants included in the study.

\section{Results}

All participants indicated that they had done RYGB aiming to reach normal BMI and expected to be able to stay in this weight range. At the time of the interview, two participants presented normal BMI. Ten participants were overweight, and three participants were obese, this may be indicative of the difficulty in maintaining low weight despite performing the procedures (RYGB and APC). The number of APCs ranged from one to seven, indicating that even after the procedure most participants were unable to maintain their normal BMI. Weight loss outcomes after RYGB is expressed in Table 2 and after APC in Table 3. 
Tais Martins • Gislei Mocelin Polli • Ana Maria Justo

Table 2 - Weight Loss RYGB

\begin{tabular}{|c|c|c|c|c|}
\hline & $\begin{array}{l}\text { BMI pre } \\
\left(\mathrm{kg} / \mathrm{m}^{2} .\right)\end{array}$ & Change in BMI & $\begin{array}{c}\text { TWL } \\
(\%)\end{array}$ & EWL \\
\hline $\mathrm{P} 1$ & 36.20 & 12.80 & 35.34 & 1.14 \\
\hline P2 & 44.43 & 18.37 & 41.35 & 0.95 \\
\hline P3 & 36.75 & 10.09 & 27.45 & 0.86 \\
\hline P4 & 37.46 & 10.41 & 27.78 & 0.84 \\
\hline P5 & 38.82 & 12.31 & 31.71 & 0.89 \\
\hline P6 & 38.67 & 10.78 & 27.88 & 0.79 \\
\hline P7 & 45.55 & 12.49 & 27.42 & 0.61 \\
\hline P8 & 41.05 & 11.11 & 27.07 & 0.69 \\
\hline P9 & 45.48 & 19.78 & 43.48 & 0.97 \\
\hline P10 & 38.22 & 19.11 & 50.00 & 1.45 \\
\hline P11 & 39.01 & 18.73 & 48.00 & 1.34 \\
\hline $\mathrm{P} 12$ & 63.98 & 35.89 & 56.10 & 0.92 \\
\hline $\mathrm{P} 13$ & 50.00 & 17.97 & 35.94 & 0.72 \\
\hline $\mathrm{P} 14$ & 50.19 & 25.10 & 50.00 & 1.00 \\
\hline $\mathrm{P} 15$ & 40.13 & 16.61 & 41.38 & 1.10 \\
\hline Mean & 46.72 & 16.77 & 38.06 & 1.07 \\
\hline SD & 9.10 & 6.89 & 9.89 & 0.25 \\
\hline
\end{tabular}

$\%$ TWL $=$ Percent of total weight loss

The corpus for the analysis of obesity-related SRs came from 15 texts comprising 266 text segments (TS), 224 of which (84.21\%) were con- sidered in $\mathrm{DHC}$. DHC results are shown in the Dendrogram (Figure 1).

Figure 1 - DHC Dendrogram about Obesity Social Representations

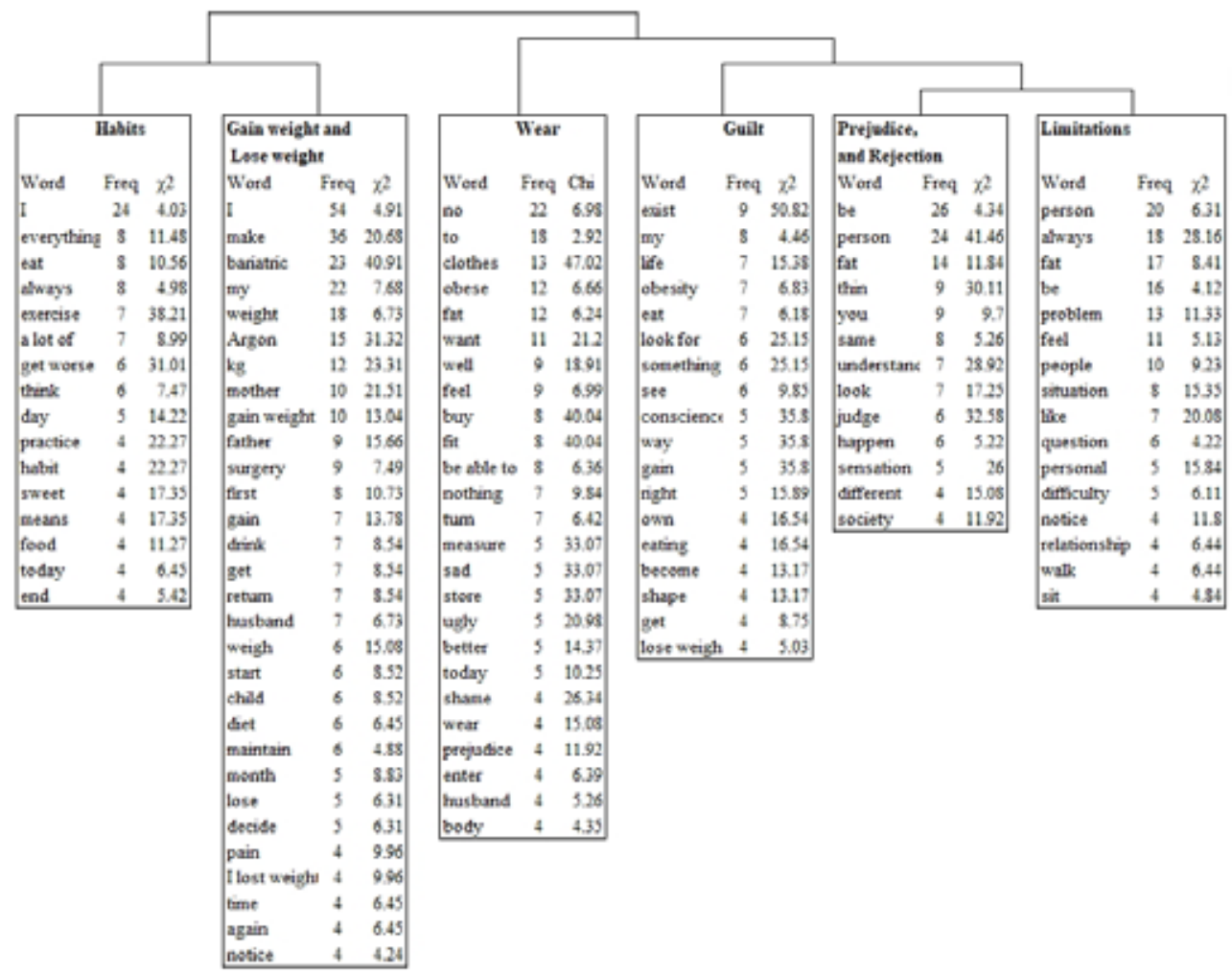


The Habits Class was composed of 27 TS, representing $12.05 \%$ of the corpus. The segments that make up this class are formed by words such as: habit, get worse, change, increase, food, gained weight, exercise. It shows the difficulty in adopting adequate eating habits and adhering to a regular practice of physical activities. The following account illustrates the content of this class:

But I was too overweight at the time, so I could not do it, and in this cycle of not being able to practice sports, I ended up entering the food cycle to fill the lack of sports, and then I gained more weight, that is, an eternal vicious cycle of obesity. (P 5; male; 52 years; BMI 26.51; 2 APCs)

The Gaining and Losing Weight class was composed of 65 TS, representing $29.02 \%$ of the corpus, and refers to the choice of bariatric surgery and APC. The segments that make up this class are formed by words such as: bariatric, argon, gain weight, lose weight, can, pain. It refers to the need to fit the standards, so RYGB and APC emerge as something that brings hope to solve the weight problem.

When I got married, I weighed $58 \mathrm{~kg}$ and started gaining weight after pregnancy. That was until I was 30. The diets used to solve my problem, but the tendency to gain weight won, and from my $58 \mathrm{~kg}$ there I went to $115 \mathrm{Kg}$ when I had my first bariatric surgery, because at the time I thought my husband had another woman, and that was very complicated, because he is very handsome and I was fat and did not have many clothing options to go out with. (P. 9; female; 44 years; BMI 29.67; 5 APCs)

The Wear class was composed of 30 TS, representing $13.39 \%$ of the corpus. The segments that make up this class are formed by words such as: measure, shame, prejudice, sad, fit, ugly, wear, body, obese, fat, feel, buy. The content addresses the difficulties experienced by participants in buying clothes appropriate to their weight, illustrating the impact of obesity on participants' self-esteem. "It is hard when you walk into a store and the salesperson says there are no clothes for your size, and I have heard it several times until surgery" (P. 4; female; 38 years; BMI 27.47; 1 APC).

Next to the wear class, the Guilt class was composed of 28 TS, representing $12.05 \%$ of the corpus. The segments that make up this class are formed by words such as: conscience, wrong, quality, guilt, eating, gain, look for. There is clarity about the origin of overweight, which reflects in the feeling of guilt for this condition.

\begin{abstract}
Becoming obese was partly my fault, and I did not find other ways to try to avoid it. What appears is my conscience, because it comes from the person itself, as if they knew that there are limits and controls. (P. 8; male; 34 years; BMI 29.94; 1 APC)
\end{abstract}

The Prejudice and Rejection class was composed of 30 TS, representing $13.39 \%$ of the corpus. The segments that make up this class are formed by words such as: judge, thin, understand, sensation, rejection, suffering, discomfort, understand, different, society, and social judgment is a key element and a generator of suffering. The social constraints include rejection and external judgment, which often interfere with work and social life. These factors are related to the desire to change. "For me, being fat is something uncomfortable that hinders movement and promotes a certain kind of rejection, because people's judgment is very strong and people judge an obese person as someone irresponsible, and that irresponsibility affects everything." (P. 14; female; 47 years; $\mathrm{BMI} 29.40 ; 7$ APCs)

The Limitations class, composed of 44 TS, represents $19.64 \%$ of the corpus. Words such as problem, fat, situation, always, relationship, person and difficulty can be highlighted. This class deals with the physical restrictions imposed by obesity, including health problems; which refer to the concrete situations that limit obese people. "Notoriously, overweight is a limiting factor for people, because obesity is very complicated, it is a limiting factor even at work." (P. 15, female; 53 years; BMI 18.34; 1 APC)

\section{Discussion}

This study sought to identify the socially shared knowledge about obesity among people who have undergone bariatric surgery (RYGB) and at 
least a second endoscopic intervention to reduce gastrojejunal anastomosis (APC). The socio-representational perspective allowed identifying ways of thinking about obesity that are shared in society and that are related to the search for weight loss with surgical intervention. By understanding the meanings attributed to obesity by people who experienced weight relapse, even after surgical procedures, one can think of alternative and more effective ways of helping people to be successful, through psychological, nutritional and educational support, such as for example, through therapeutic education, whose success has already been verified in relation to other chronic diseases (Apostolidis et al., 2020; Fonte et al., 2017).

The data showed the difficulty in maintaining weight after undergoing bariatric surgery, which is why participants sought APC once or more. It should be highlighted that overweight and body changes interfere with self-esteem, mood, health, social acceptance and rejection. The first two classes (those left in the dendrogram) were different from others in DHC, revealing a search for weight loss and difficulty in adopting new habits. These classes demonstrate the reality experienced by the research participants and bring part of the history of each one. Difficulties in changing habits and maintaining weight seem to be associated with weight relapse after bariatric surgery (González-Cutre et al., 2018; Marchesini \& Antunes, 2017).

In turn, the other four classes refer to the suffering experienced by obese people, which appears directly in social relationships. In this sense, Justo et al. (2018) point out that a major obstacle to weight control is precisely the social pressure that involves being fat in our society. These classes provide clues to answer the question that motivated the present research. They present knowledge socially shared by people who experience obesity, indicating difficulties and suffering resulting from this condition. Being obese means failing and, therefore, carrying guilt. The obese person faces daily difficulties in getting around, occupying a space in public transportation and buying clothes, for example.

In addition, they suffer daily social rejection and prejudice. He feels judged, because obesity is as- sociated with a lack of self-control and willpower by non-obese people. Obesity is a complex condition, with repercussions in psychosocial spheres, especially in terms of the prejudice suffered (Araújo et al. 2018; Koelzer et al., 2016). Although body fat acts as a stigma (Goffman, 1988), it is considered a reversible attribute by the medical community, patients and society (Carof, 2017). As a result, the disapproval of obesity shown in social relationships and in the prejudice experienced by participants also involves psychological aspects. As pointed out by Vigarello (2010), not meeting the desirable weight reflects an inability to control oneself, which affects patients' self-esteem, since a change in body shape is invariably considered possible. Obesity SRs refer to a phenomenon that is both individual and collective, because it transits between the image of oneself and the images constructed by the collectivity.

Obesity was found to be strongly negatively represented by individuals who underwent RYGB and APC, so surgical procedures were the alternatives found due to the difficulties in losing or maintaining weight. Although the results of RYGB and APC did not allow the participants of this research to reach the desired BMI, they consider these procedures as appropriate means to this end, which is shown by the repeated times they undergo APC. The suffering that goes along with obesity and the difficulty in changing habits seem to be associated with the search for surgical help for a solution they believe to be definitive, even though their own experience has shown weight relapse. In other words, subsequent failures in previous attempts of weight loss generate the belief of inability to achieve the desired weight without external aid, which, unrealistically, is seen as something that can be achieved by surgical procedures, as well as observed by Vuuren et al. (2016).

The SR approach allowed identifying how beliefs widespread in society about obesity are shared by people who were in this condition and sought more than once surgical assistance as a solution. Although their personal experiences showed failure to lose the desired amount of weight from the first surgical intervention, new 
interventions were used to achieve a definitive solution. The content of the interviews indicated that socially shared beliefs about obesity have great strength in the face of these people's decision to undergo invasive treatments, without guarantee of success. Now, although it can be said that bariatric surgery is a definitive solution for weight loss, the patients in this study experienced something different. However, the experience itself has not shown to be stronger than the socially shared knowledge about obesity.

Experiences of rejection, prejudice, difficulties and failures accumulated throughout life added to the negative beliefs about obesity. Thus, the idea that they cannot succeed without help and the desire to adapt to the corporal pattern of socially imposed thinness, may be at the basis of the decision to undergo subsequent surgical procedures. There is no guarantee of success, but not doing a new procedure for these people is certainly a guarantee of new failure.

\section{Conclusions}

Although it had the participation of only 15 individuals, this research indicates important ways to include psychosocial variables in the understanding of obesity-related phenomena, expanding the look of individual biological understanding to a broad view on obesity and its implications for identity and social formation and the adoption of practices for weight reduction and maintenance. For a broad understanding of obesity-related health factors, it would be important to investigate psychological aspects related to weight relapse in patients who underwent to surgical interventions for weight reduction, to expand the knowledge produced by this research.

\section{Declaration of conflicting interests}

The authors declared no potential conflicts of interest with respect to the research, authorship and/or publication of this article.

\section{Funding}

This research was not supported by any foundation.

\section{References}

Apostolidis, T., Fonte, D., Alessio, R. L. S., \& Santos, M. d. F. S. (2020). Representações sociais e educação terapêutica: questões teórico-práticas. Saúde e Sociedade, 29(1), 1-11. https://doi.org/10.1590/S0104-12902020190299

Araújo, L. S., Coutinho, M. d. P. L., Alberto, M. d. F. P., Santos, A. M. D., \& Pinto, A. V. d. L. (2018). Discriminação baseada no peso: Representações Sociais de Internautas sobre a gordofobia. Psicol. estud., 23, 1-17. https:// doi.org/10.4025/psicolestud.v23.e34502

Barros, F. (2015). Qual o maior problema de saúde pública: a obesidade mórbida ou a cirurgia bariátrica no Sistema Único de Saúde (SUS)? (Parte II). Rev. Col. Bras. Cir., 42(3), 136-137. https://doi.org/10.1590/010069912015003001

Brunaldi, V. O., Jirapinyo, P., Moura, D. T. H., Okazaki, O., Bernardo, W. M., Galvão Neto, M., Campos, J. M., Santo, M. A., \& Moura, E. G. H. (2018). Endoscopic Treatment of Weight Regain Following RouX-en-Y Gastric Bypass: a Systematic Review and Meta-analysis. Obes Surg, 28(1), 266-276. https://doi.org/10.1007/s11695-017-2986-x

Carof, S. (2017). Les représentations sociales du corps «gros ». Un enjeu conflictuel entre soignants et soignés. Anthropologie \& Santé, 14(1), 1-22. https://doi. org/10.4000/anthropologiesante.2396

Christensen, B. J., Schmidt, J., Nielsen, M., Tækker, L., Holm, L., Lunn, S., Bredie, W., Ritz, C., Holst, J., Hansen, T., Hilbert, A., Le Roux, C., Hulme, O., Siebner, H., Morville, T., Naver, L., Floyd, A., \& Sjödin, A. (2018). Patient profiling for success after weight loss surgery (GO Bypass study): An interdisciplinary study protocol. Contemporary Clinical Trials Communications, 10, 121-130. https://doi. org/10.1016/j.conctc.2018.02.002

Fonte, D., Colson, S., Côté, J., Reynaud, R., Lagouanelle-Simeoni, M.-C., \& Apostolidis, T. (2017). Representations and experiences of well-being among diabetic adolescents: Relational, normative, and identity tensions in diabetes self-management. Journal of Health Psychology, 24(6), 1-27. https://doi.org/10.1177/1359105317712575

Goffman, E. (1988). Estigma: Notas sobre a Manipulação da Identidade Deteriorada. LTC.

González-Cutre, D., Megias, Á., Beltran-Carrillo, V., Cervelló, E., \& Spray, C. (2018). Effects of a physical activity program on post-bariatric patients: A qualitative study from a self-determination theory perspective. Journal of Health Psychology, 1-12. https://doi. org/10.1177/1359105318770729

Herzlich, C. (2017). A journey in the field of health: from social psychology to multi-disciplinarity. Journal of Health Psychology, 23(3), 1-11. https://doi. org/10.1177/1359105317709474

HF. (2017). VIGITEL Brasil 2016. Risk factors surveillance and disease protection phone chronicle surveys. Health Ministry.

Jodelet, D. (2001). Representações sociais: um dominio em expansão. In D. Jodelet (Ed.), As representações sociais (pp. 17-44). EdUERJ 
Justo, A. M., Camargo, B. V., \& Boulsfield, A. B. (2018). Sobrepeso e controle de peso: pensamento leigo e suas dimensões normativas. Psicologia: Teoria e Prática, 20(20), 213-224. https://doi.org/10.5935/1980-6906/ psicologia.v2on2p213-224

Koelzer, L. P., Castro, A., Bousfield, A. B. S., \& Camargo, B. V. (2016). O "olhar preconceituoso": Representações sociais sobre fotografias nas redes sociais. Estudos e Pesquisas em Psicologia, 16(2), 431-449. https://doi. org/10.12957/epp.2016.29169

Latner, J., \& Ciao, A. (2013). Weight-loss history as a predictor of obesity treatment outcome: Prospective, long-term results from behavioral, group self-help treatment. Journal of health psychology, 19(2), 1-9. https:// doi.org/10.1177/1359105312468191

Lima, A. C. R., \& Oliveira, A. B. (2016). Fatores psicológicos da obesidade e alguns apontamentos sobre a terapia cognitivo-comportamental. Mudanças - Psicologia da Saúde, 24(1), 1-14. https://doi.org/ 10.15603/2176-1019/ mud.v24n1p1-14

LoMonaco, G., \& Bonetto, E. (2019). Social representations and culture in food studies. Food Research International, 115, 474-479. https://doi.org/10.1016/j. foodres.2018.10.029

Magouliotis, D. E., Tasiopoulou, V. S., \& Tzovaras, G. (2019). One Anastomosis Gastric Bypass Versus Roux-en-Y Gastric Bypass for Morbid Obesity: an Updated Meta-Analysis. Obes Surg, 29(9), 2721-2730. https://doi. org/10.1007/s11695-019-04005-0

Marchesini, S. D., \& Antunes, M. C. (2017). A percepção do corpo em pacientes bariátricos e a experiência do medo do reganho do peso. Interação Psicol., 21(2), 127136. https://doi.org/10.5380/psi.v21i2.47944

Moon, R. C., Teixeira, A. F., Neto, M. G., Zundel, N., Sander, B. Q., Ramos, F. M., Matz, F., Baretta, G. A., Quadros, L. G., Grecco, E., Souza, T., Barrichello, S. A., Filho, A. C., Usuy, E. N. J., Amorim, A. M. B., \& Jawad, M. A. (2018). Efficacy of Utilizing Argon Plasma Coagulation for Weight Regain in Roux-en-Y Gastric Bypass Patients: a Multi-center Study. Obes Surg, 28(9), 2737-2744. https:// doi.org/10.1007/s11695-018-3229-5

Moura, D. T. H., Jirapinyo, P., \& Thompson, C. C. (2019). Modified-ESD Plus APC and Suturing for Treatment of Weight Regain After Gastric Bypass. Obes Surg. 29(6), 2001-2002. https://doi.org/10.1007/s11695-01903808-5

Polli, G. M., Silva, J. C. C., Pereira, M. G., Reis, R. A., Peruci, T. T., Gelinski, E. M. M., \& Gebara, T. S. S. (2018). Social representations of anorexia among university students and risk factors: possible relations. Psico PUCRS, 49(1), 12-20. https://doi.org/10.15448/1980-8623.2018.1.25251

Ratinaud, P. (2009). IRAMUTEQ: Interface de R pour les Analyses Multidimensionnelles de Textes et de Questionnaires: [Computer software]. Retrieved from http://www.iramuteq.org

Vigarello, G. (2010). Les métamorphoses du gras. Paris: Éditions du Seuil.
Vuuren, M., Strodl, E., White, K., \& Lockie, P. (2016). Psychosocial presentation of female bariatric surgery patients after multiple revisional surgeries: A qualitative study. Journal of Health Psychology, 23(10), 1261-1272. https://doi.org/10.1177/1359105316648673

WHO. (2017). Overweight and Obesity in the Western Pacific Region. An Equity Perspective. Western Pacific: WHO.

WHO. (2019). ICD - 11. International Classification of Diseases 11th Revision. The global standard for diagnostic health information. WHO.

Williams, E. P., Mesidor, M., Winters, K., Dubbert, P. M., \& Wyatt, S. B. (2015). Overweight and Obesity: Prevalence, Consequences, and Causes of a Growing Public Health Problem. Current Obesity Reports, 4(3), 363-370. https:// doi.org/10.1007/s13679-015-0169-4

\section{Tais Martins}

Mestre em Psicologia pela Universidade Tuiuti do Paraná (UTP).

\section{Gislei Mocelin Polli}

Doutora em Psicologia e mestre pela Universidade Federal de Santa Catarina (UFSC), em Florianópolis, SC, Brasil. Professora da Universidade Tuiuti do Paraná (UTP), em Curitiba, PR, Brasil.

\section{Ana Maria Justo}

Doutora e mestre em Psicologia pela Universidade Federal de Santa Catarina (UFSC), em Florianópolis, SC, Brasil. Professora da Universidade Federal de Santa Catarina (UFSC), em Florianópolis, SC, Brasil.

\section{Endereço para correspondência}

\section{Gislei Mocelin Polli}

Rua Nicarágua, 1955, apto. 705B

Bacacheri, 82515-260

Curitiba, PR, Brasil

Os textos deste artigo foram revisados pela Poá Comunicação e submetidos para validação do autor antes da publicação 